Federal Reserve Bank of Dallas

Globalization and Monetary Policy Institute

Working Paper No. 195

http://www.dallasfed.org/assets/documents/institute/wpapers/2014/0195.pdf

\title{
Doctrinal Determinants, Domestic and International, of Federal Reserve Policy 1914-1933*
}

\author{
Barry Eichengreen \\ University of California, Berkeley
}

October 2014

\begin{abstract}
This paper describes the doctrinal foundations of Federal Reserve policy from the establishment of the institution through the early 1930s, focusing on the role of international factors in those doctrines and conceptions. International considerations were at most part of the constellation of factors shaping the Federal Reserve's outlook and policies even in the high gold standard era that ended in 1933. However, neither was the influence of international factors absent, much less negligible. Nor were the Fed's policies without consequences for the rest of the world. Having described the doctrinal foundations of Federal Reserve policy, I analyze how the doctrines in question influenced the central bank's actions and shaped the impact of monetary policy on a number of key occasions, focusing in particular on episodes where the international economy and the rest of the world played an important role.
\end{abstract}

JEL codes: E4, F5

\footnotetext{
* Barry Eichengreen, University of California, Berkeley, Department of Economics, 508-1 Evans Hall, MC \#3880, Berkeley, CA 94720-3880. 510-642-2772. eichengr@econ.berkeley.edu. Prepared for the Federal Reserve Bank of Dallas conference on “The Federal Reserve System's Role in the Global Economy: A Historical Perspective,” Dallas, 18-19 September 2014. I thank the conference organizers, Michael Bordo and Mark Wynne, my discussant Harold James, and conference participants including Michael Dooley and Ted Truman for helpful conversations. The views in this paper are those of the authors and do not necessarily reflect the views of the Federal Reserve Bank of Dallas or the Federal Reserve System.
} 
Doctrinal Determinants, Domestic and International, of Federal Reserve Policy 1914-1933 ${ }^{1}$

\author{
Barry Eichengreen \\ University of California, Berkeley \\ This version, October 2014
}

\title{
1. Introduction
}

I have been asked to expand on the role of the Federal Reserve System in the international economy from its founding to the early 1930s and to revisit the themes in my book on the gold standard and the Great Depression. ${ }^{2}$ Books are not always improved by second editions; sometimes they are best left to speak for themselves. In addition, I have recently written elsewhere on the role of international factors in shaping Federal Reserve policy. ${ }^{3}$

For these reasons I will take a somewhat different approach to the mission with which I have been tasked. I will describe the doctrinal foundations of Federal Reserve policy from the establishment of the institution through the early 1930s, focusing on the role of international factors in those doctrines and conceptions. My conclusion is that international considerations were at most part of the constellation of factors shaping the Federal Reserve's outlook and policies even in the high gold standard era that ended in 1933. However, neither was the influence of international factors absent, much less negligible. Nor were the Fed's policies without consequences for the rest of the world. Having described the doctrinal foundations of Federal Reserve policy, I will then analyze how the doctrines in question influenced the central bank's actions and shaped the impact of monetary policy on a number of key occasions, focusing in particular on episodes where the international economy and the rest of the world played an important role.

The doctrinal foundations of Federal Reserve policy were disputed, of course, from the institution's very creation, and in some sense even before. And those doctrinal foundations have continued to be disputed by observers of the central bank, both contemporary observers, including some within the Federal Reserve System, and historians. Different monetary policy makers have always conceived of their task differently. Their different conceptions have not always been consistent; indeed they have sometimes clashed openly. Understanding the role of these different doctrines thus entails analyzing their interplay. It means critically evaluating the work of monetary historians who may have exaggerated the influence of some doctrines relative to others. And it requires examining the role of those competing doctrines or conceptual frameworks in instances when policy makers made consequential decisions.

The approach taken here has several advantages for the task at hand. It highlights the role of ideas in the formulation and execution of policy. Ideas are not everything; in central

\footnotetext{
${ }^{1}$ Prepared for the Federal Reserve Bank of Dallas conference on "The Federal Reserve System's Role in the Global Economy: A Historical Perspective,” Dallas, 18-19 September 2014. I thank the conference organizers, Michael Bordo and Mark Wynne, my discussant Harold James, and conference participants including Michael Dooley and Ted Truman for helpful conversations.

${ }^{2}$ The earlier work in question being Eichengreen (1992).

${ }^{3}$ In Eichengreen (2013).
} 
banking as in other spheres of public policy, outcomes are shaped also by interests, by institutions, and by other factors. ${ }^{4}$ But ideas were especially important, I would argue, in this early period when initial conceptualization of the appropriate conduct of Federal Reserve policy was taking place.

In addition, the approach taken here emphasizes the role of individuals as the carriers of ideas. Doctrine influences policy only when individuals involved in the policy-making process make a compelling case that the principles or framework in question provide useful guidance and answers to the questions at hand. Doctrines need advocates in order to influence policy. Proponents of a particular doctrinal point of view need to be able to convince their colleagues of the merits of their way of viewing the policy problem. Emphasizing the importance of doctrine in informing the actions of the Federal Reserve thus directs attention to the role of persuasion, personnel and personality in the making of monetary policy.

The approach here also serves to usefully highlight the fact that no single doctrine has served to inform and guide Federal Reserve policy. The appropriate doctrinal foundations of U.S. monetary policy were (and are) disputed. The influence of competing doctrines has waxed and waned with circumstance, personnel and personality. Some will argue that this is always the case; I would argue that it was especially true in the U.S. central bank's formative years.

Finally, this approach focusing on the doctrinal foundations of Federal Reserve policy highlights how the decentralized structure of the early System provided an especially fertile seedbed for competing central banking doctrines. Different doctrines could develop and dominate in different parts of the system. At several key junctures this gave rise to disagreements among Reserve Banks. Unchecked, it threatened the coherence of monetary policy.

A final clarification before proceeding: in this discussion of the role of international factors in the conduct of Federal Reserve policy, it will be important to distinguish several different senses in which international considerations could have influenced decision making. First, the Fed could have organized policy around an international target or external economic indicator. It could have adopted an exchange rate target (as it did in this period by pegging the dollar price of gold and maintaining a minimum statutory ratio of gold reserves to monetary liabilities) and adapted policy accordingly (something that will have to be established). Second, the Fed could have adjusted its policies so as to influence economic and financial conditions in other countries, because developments abroad had a significant impact on the American economy and thereby affected the Fed's ability to meet its domestic, or internal, objectives. ${ }^{5}$ Third, the Fed could have adjusted its policies with problems in other countries in mind because it cared about the problems of those other economies, independently of any immediate impact on the U.S. economy. Finally, the Fed could have adjusted its policies with international considerations in mind because it was concerned with stability of the international monetary and financial system as a whole.

\footnotetext{
${ }^{4}$ For reviews of some of the relevant literature in political science, see Goldstein (1994) and Hay (2004).

${ }^{5}$ Modern observers refer to these as the "spillover" and "spillback" effects of monetary policy.
} 
In what follows I will argue that international considerations, in all four of these senses, played a role in the formulation of Federal Reserve policy at some point in the course of the central bank's first two decades.

\section{Doctrinal Foundations}

Federal Reserve policy between 1914 and 1933 was informed not by one doctrine but by several. In this section I lay out those competing doctrines and describe the contexts in which they arose.

Gold Standard Doctrine. When the Federal Reserve System was created, the United States was on the gold standard. Specie resumption, following its suspension during the Civil War, was completed in 1879. The Gold Standard Act of 1900 then cemented the gold-based nature of the country's monetary circulation. ${ }^{6}$ Gold coinage was free, gold could be held by individuals and financial institutions, and paper currency was convertible into gold coin. Member banks were required by the Federal Reserve Act, signed into law in December 1913, to pay in their capital subscriptions in gold or gold certificates (U.S. Treasury certificates previously issued to the public that were 100 per cent secured by gold in the Treasury). Federal Reserve Banks were required, in turn, to hold gold as backing for their liabilities. Specifically, they were required to maintain gold reserves equal to at least 40 per cent of their outstanding notes and 35 per cent of their deposit liabilities. Those gold reserves were then used to settle payments between Federal Reserve districts arising out of check clearings and other transactions, via transfers from the account of one Reserve Bank to another through the Interdistrict Settlement Fund. ${ }^{7}$

The maintenance of an adequate gold cover for the central bank's liabilities was thus a foundation of policy from the point in time when the U.S. central bank opened its doors in 1914 to the suspension of gold convertibility in 1933. Backing in the amount of 35 to 40 per cent of liabilities, a proportion not atypical of contemporary central banks, was seen as important for confidence and for what academics and officials today refer to as the credibility of policy. It followed that the conventions of the gold standard ("rules," the term favored by Keynes in 1925, is too strong) were important for shaping the outlook of Federal Reserve officials and the policies of the system. ${ }^{8}$ Losses of gold were seen as signaling the need to raise discount rates to prevent reserves from falling further (since discounting bills was a way of injecting notes into circulation and, indirectly, of influencing deposits). Increases in reserves indicated that circumstances were propitious for cutting rates and making credit more freely and cheaply available through the discount window. Capital inflows and outflows (external drains) were of particular importance for reserve districts such as New York closely connected to international markets.

This said, the Federal Reserve Act mandated only maintenance of a minimum reserve ratio, not the continuous maintenance of a specific reserve ratio. From the outset, the Reserve

\footnotetext{
${ }^{6}$ The 1900 act unambiguously fixed the value of the dollar at 25 8/10ths grains of gold of 90 per cent purity (equivalent to \$20.67 per troy ounce), effectively demonetizing silver.

${ }^{7}$ See Eichengreen, Chitu, Mehl and Richardson (2014).

${ }^{8}$ The phrase used by Keynes in The Economic Consequences of Mr. Churchill (1925).
} 
Banks and the system as a whole had more gold than required courtesy of member bank subscriptions. ${ }^{9}$ During World War I, large inflows from embattled Europe then pushed the ratio of gold reserves to note liabilities to more than 84 per cent (in March 1917). That ratio declined when the U.S. entered the war but still stood at nearly 50 per cent at the conclusion of hostilities. The same was true for much of the 1920s, with a few exceptions highlighted below.

All this provided scope for creative interpretation of the conventions of the gold standard. It allowed the Federal Reserve System to sterilize gold movements when it so chose. Meltzer (2003), focusing on the period 1923-29, shows that there were instances where the central bank sterilized both inflows and outflows in the short run, although it did not ignore the gold standard rules in the long run. ${ }^{10}$ His analysis, like that of Hardy (1932), points to stricter adherence to the gold standard rules before 1925 than after.

But, irrespective of whether or not the minimum reserve ratios of the gold standard bound, gold standard doctrine still influenced policy. The gold standard was not simply a set of constraints on the operation of monetary policy; it came packaged with a set of priorities and a mind-frame for central bankers. ${ }^{11}$ Maintenance of the gold parity was paramount. If a minimum gold ratio was required for a minimum of confidence, then accumulating and maintaining additional gold over and above the minimum was useful for gaining additional confidence. Changes in the domestic price of gold - external devaluation - could fatally undermine that selfsame confidence; instead, internal devaluation (reductions in wages and prices) was required in response to adverse shocks. Although the central bank could not remain passive in the event of such shocks, the burden of adjustment fell mainly on other parties and markets.

Real Bills Doctrine. The real bills doctrine - the idea that the central bank should provide just as much money and credit as needed to accommodate the legitimate needs of commerce but not finance speculative activity - long predated the founding of the Fed. The central ideas are in the work of John Law (1705), writing in the aftermath of the founding of another important central bank, the Bank of England. They were echoed in Adam Smith's Wealth of Nations. ${ }^{12}$ They were championed by members of the Banking School in the mid- $19^{\text {th }}$ century. Importantly, they were central to the thinking of such late- $19^{\text {th }}$ and early- $20^{\text {th }}$ century American banking and monetary reformers as Charles Conant, J. Laurence Laughlin and H. Parker Willis.

They were therefore enshrined in the Federal Reserve Act. The act's preamble spoke of the desirability of an "elastic currency" that expanded and contracted as needed to accommodate production and trade. ${ }^{13}$ The act instructed Reserve Banks to extend credit by rediscounting the short-term, self-liquidating paper presented to them by commercial banks. Limiting its discounts to such eligible paper ensured that the new central bank would be providing support for wholesome activities like trade and production while not encouraging unhealthy financial

\footnotetext{
${ }^{9}$ These excess reserves came to some $\$ 138$ million (or 7 per cent of the country's monetary gold) as of December 31, 1914 when the first round of capital subscriptions was complete.

${ }^{10}$ Meltzer (2003), p.172.

${ }^{11}$ Peter Temin and I (2000) refer to this as the gold standard mentalité.

${ }^{12}$ As analyzed by Laidler (1981).

${ }^{13}$ It spoke of the importance of "accommodating [the needs of] commerce and business."
} 
speculation. Tying the extension of central bank credit to trade and production was a way of anchoring policy in a period when the constraints of the gold standard did not bind. The practice of discounting real as opposed to fictitious bills was seen as ensuring that the central bank did not abuse its ample monetary powers by providing dangerously large amounts of credit for speculative financial purposes. And discounting only self-liquidating bills meant that there was no danger of chronic credit expansion and inflation.

Some contemporary monetary experts were aware that adherence to the real bills doctrine could lend a dangerously procyclical cast to monetary policy. A. Piatt Andrew, assistant professor of economics at Harvard University at the time (and later assistant to the National Monetary Commission and Assistant Secretary of the Treasury), emphasized the point in $1905 .{ }^{14}$

Nonetheless, the real bills doctrine found a ready reception within the Federal Reserve System. As Humphrey (2001) describes, economists on the Federal Reserve Board such as Adolph Miller (a student of Laughlin and subsequently professor of economics at the University of California, Berkeley) and influential Reserve Bank governors like George Norris of Philadelphia and James McDougal of Chicago initially advanced a relatively pure and unvarnished version of the doctrine. They explained how the real bills doctrine could be implemented through the central bank's rediscounting function and, eventually, open market operations. These ideas pointed to member bank borrowing (via rediscounts) and market interest rates (as influenced by open market operations) as indicators of whether the Fed was succeeding in providing an elastic currency. These adherents to the real bills doctrine, who dominated both the Board and the Reserve Banks, grew increasingly influential in the course of the 1920s and especially following the death in 1928 of Benjamin Strong, the powerful governor of the Federal Reserve Bank of New York, who held rather different views. ${ }^{15}$

Riefler-Burgess Doctrine. Closely related to the real bills doctrine was the RieflerBurgess Doctrine, a term coined by Brunner and Meltzer (1968). This arose out of observations on the part of W. Randolph Burgess, publications head of the statistics department of the Federal Reserve Bank of New York, and Winfield Riefler, an economist at the Board, concerning the interaction of discount-window borrowing and open market operations. Riefler and Burgess discovered the tendency for changes in discount-window borrowing and open market operations to offset one another. They showed that when the Fed provided the banks with more cash via open market purchases of securities, they had less need to turn to the discount window, and vice versa. And when the Fed purchased securities or rediscounted on behalf of one Reserve Bank, other Reserve Banks had less occasion to apply to the discount window, since credit could flow between Federal Reserve districts via the interbank market.

The discovery was inadvertent; it occurred in 1922 when the Reserve Banks first purchased government securities not to manage money and credit conditions but simply to augment their earning assets. Nonetheless, the implications were profound. As Burgess (1964) described the lessons, "First, as fast as the Reserve Banks bought Government securities in the market, the member banks paid off more of their borrowings; and, as a result, earning assets and

\footnotetext{
${ }^{14}$ See Andrew (1905).

${ }^{15}$ This is the conclusion of both Friedman and Schwartz (1963) and Timberlake (2005). For more on Strong, see below.
} 
earnings of the Reserve Bank remained unchanged. Second, they all discovered that the country's pool of credit is all one pool and money flows like water throughout the country."

It followed that neither the quantity of discounts nor the extent of open market operations was an adequate gauge of policy, since the two instruments were near-perfect substitutes from the point of view of credit creation. Neither was the expansion and contraction of commercial bank balance sheets in a particular Federal Reserve district, New York for example, especially informative since balance sheets in the different centers were linked by interdistrict flows. The only statistic adequate for capturing the stance of policy was the level of interest rates prevailing in the market. When market interest rates were high, rediscounting and credit injected via open market operations were insufficient to meet the needs of business and commerce, and conversely when market rates were low. Reifler, Burgess and their followers placed particular emphasis on short-term interest rates, given that rediscounting by banks was the incremental source of credit on the margin and the bills so rediscounted were short-term and self-liquidating.

The close connection between this emphasis on short-term market interest rates as a measure of the stance of policy in the Riefler-Burgess Doctrine and the central implication of the real bills doctrine will be clear. Also evident is a certain ambiguity about what is meant by market interest rates and the potential for confusion between real and nominal rates, as is the potential for a procyclical bias in monetary policy. The main difference from the real bills doctrine was that Riefler and Burgess acknowledged the role for activist policy - the central bank could actively influence credit conditions if it so chose through open market operations rather than limiting its operations to passively rediscounting real bills.

Warburg Doctrine. Paul Warburg was a German-American banker, tireless campaigner for a U.S. central bank, and frequent interlocutor of the National Monetary Commission. He was a member of the Federal Reserve Board from its founding in 1914 and vice governor from 1916 until his resignation in 1918. He continued to advise the System as a member of the Federal Advisory Council in the 1920s. Warburg was conversant with monetary arrangements in Europe, and he saw the creation of a central bank to backstop a market in bankers' acceptances as enhancing the efficiency of U.S. credit markets and boosting the competitiveness of the American economy. A market in trade acceptances generated in the course of international transactions would be especially advantageous, in his view, for the competitiveness of U.S. exports (Warburg having started out in the business of financing exports in Germany). ${ }^{16}$

Thus, Warburg saw an important role for the Fed as promoting the development of this missing market in trade acceptances and fostering international use of the U.S. dollar. Starting in 1914, the Guarantee Trust Company of New York began originating trade acceptances, and other U.S. banks, notably National City Bank, quickly followed. These banks preferred, as banks do, to take their commission and sell the resulting asset on to other investors, the problem being that domestic demand for this still relatively unfamiliar asset was relatively narrow (and in the circumstances of World War I, European demand could not be tapped). This made the price of these instruments relatively volatile, which only reinforced the narrowness and underdevelopment of the market.

\footnotetext{
${ }^{16}$ Warburg's interest in developing a market in trade acceptances, and how his initiatives were received, are described more fully by Broz (1997).
} 
Hence the role for the Fed as market maker. It purchased trade acceptances when private demand was weak and their prices showed signs of falling below prevailing levels, or (equivalently) when interest rates on dollar trade credit showed signs of rising relative to interest rates on alternative sources (the principal alternative source being sterling trade credit in London). Between 1917 and 1919 and for much of the 1920s, the Federal Reserve Banks regularly bought and held as much as two-thirds of total outstanding acceptances (less in 1929 and the early 1930s when private demand for these relatively safe assets was strong, more in other periods like 1917 and 1927 when private demand was weak). ${ }^{17}$

Warburg's view that the Federal Reserve should serve as market maker in order to foster financial development, and dollar internationalization in particular, was widely shared. It was shared, specifically, by Benjamin Strong, governor of the Federal Reserve Bank of New York. Strong subscribed to Warburg's arguments about the connections between a liquid market in trade acceptances and the competitiveness of U.S. exports. He also appreciated that the existence of a market in trade acceptances in London provided the Bank of England with a convenient lever for managing credit conditions. ${ }^{18}$

And what Strong believed, a majority on the Federal Reserve Board also believed (not for the last time). Thus, the Board quickly authorized the Reserve Banks to purchase trade acceptances for their own account, initially restricting the maturity of the bills in question (so that the transactions would be self-liquidating) but eventually giving the Reserve Banks discretion over maturities. While this idea that the Fed should act as market maker and currency internationalizer never dominated other priorities, it was a significant aspect of U.S. central bank doctrine in the 1920s. ${ }^{19}$

Not everyone views the resulting policies in a favorable light. Rothbard argues that this policy of "unconditional support" for the acceptance market prevented the Federal Reserve from stemming the expansion of credit in the late 1920s, ultimately with disastrous consequences. ${ }^{20}$ Other like Hardy reject the accusation, concluding that Federal Reserve support for the acceptance market never achieved levels where it seriously distorted policy. ${ }^{21}$

Strong Doctrine. Friedman and Schwartz (1963) argue that Federal Reserve policy through 1928 was shaped by the influential views of Benjamin Strong. Strong's views are not easily summarized. He believed in the desirability of fostering the market in trade acceptances, as we have seen, through System operations as acceptance buyer of last resort. He was sensitive to the role of the central bank in managing the financial system, situated as he was at the epicenter of U.S. financial markets and having been involved in managing the last major financial crises in 1907 and 1914. Strong was advised by Irving Fisher and other economists who emphasized price-level targeting (price-level stabilization in contemporary parlance) as a

\footnotetext{
${ }^{17}$ Details are from Eichengreen and Flandreau (2012).

${ }^{18}$ See Chandler (1958), p.86-91.

${ }^{19}$ Nor did it necessarily dominate Benjamin Strong's own other priorities, as we will see below.

${ }^{20}$ Rothbard (2011), p.723.

${ }^{21}$ See Hardy (1932), chapter 12.
} 
goal of policy. ${ }^{22}$ He was also close to foreign central bankers like Bank of England Governor Montagu Norman, attuning him to the role of the U.S. central bank in helping to manage the gold-standard system. Along with the sympathy he felt for foreign central banks, Strong understood that the U.S. depended increasingly on international trade and finance, and that the stable exchange rates of the gold standard worked to the advantage of the country by encouraging commodity exports and foreign lending.

Having embraced these myriad goals, it followed that Strong was no rigid adherent of the real bills doctrine. Rather than looking exclusively at the level of interest rates, he looked also at money and credit aggregates when gauging the stance of policy and at price-level changes when evaluating the effects. He was a believer in discretionary policy: he opposed formal rules for targeting stable prices and specifically came out against Congressional legislation to this effect. ${ }^{23}$ He was comfortable with using the Fed's discretionary powers to sterilize gold inflows in violation of conventional gold-standard doctrine if doing so was necessary to achieve other targets, such as a stable price level.

This, of course, also created a tension with Strong's desire to support a stable international monetary system, since the sterilization of gold inflows could lead to chronic gold losses for other countries. On other occasions like 1924 and 1927 when Strong prioritized these international considerations, his policies might pay downplay the implications for domestic price and financial stability. These conflicts point to the fundamental shortcoming of the Strong Doctrine, namely, that it sought to pursue multiple objectives with limited instruments.

Harrison Doctrine. George Harrison succeeded Benjamin Strong as governor of the Federal Reserve Bank of New York on Strong's death in November 1928 and occupied that position in the late stages of the Wall Street boom, during the Crash and through the depths of the Great Depression. It is therefore interesting to ask whether there was such a thing as a Harrison Doctrine as distinct from the Strong Doctrine.

Friedman and Schwartz argue that Fed policy changed with Strong's succession by Harrison; it became more restrictive in the late stages of the expansion and less accommodating in the slump. ${ }^{24}$ Others like Wheelock (1991) and Meltzer (2003) see continuity where Friedman and Schwartz see change. If there was a change it was not in doctrine, in their view, but rather in the ability of the head of the New York Fed to build the consensus needed to implement his policies. Where Strong was willful and assertive, Harrison was thoughtful and reflective; in the turbulent circumstances of the early 1930s he was unable to unify his colleagues behind his policies. The difference, in this view, was one of temperament, not of doctrine.

Such a conclusion is not surprising, since Harrison served as Strong's deputy for the better part of nine years. Harrison shared Strong's view of the desirability of maintaining the gold standard. He shared his predecessor's view that the Federal Reserve had an important role in the maintenance of financial stability. The statement might seem peculiar given the three banking crises occurring on his watch but it is no less accurate for the fact. Harrison moved aggressively to rein in what he perceived as excesses on Wall Street by raising the cost of

\footnotetext{
${ }^{22}$ Hetzel (1985), pp.7-8.

${ }^{23}$ Timberlake (2005), p.212.

${ }^{24}$ Friedman and Schwartz (1963), pp.411-417.
} 
brokers loans, and following the Crash in October 1929 he acted, without the express permission of the Board, to flood financial markets with liquidity. Like Strong, Harrison appreciated the role of the Federal Reserve in providing the global public good of international monetary stability. He was sympathetic to Reichsbank President Hans Luther's application for an emergency loan in the summer of 1931 but lacked the gumption to move ahead without the cooperation of the Bank of England and Bank of France, which was not forthcoming.

If there was a doctrinal difference between Harrison and Strong, it was one of shading. Harrison was perhaps less attuned to the role of the central bank in the maintenance of price stability and more inclined to the Riefler-Burgess Doctrine. Harrison was not as close to Irving Fisher and other members of the Stable Money Association. Less experienced than Strong in technical aspects of money and finance, he was more inclined to defer to other Federal Reserve officials when they interpreted events in terms of the Riefler-Burgess Doctrine. Thus, he was prepared to conclude from the fact that interest rates were low after 1929 that monetary policy was accommodating. Although Harrison occasionally advocated open market purchases, he did so on other, very specific grounds - that they would help to stabilize the international system, that they would address specific risks to financial stability, and that they were needed to fend off political threats to the integrity of the central bank - and not because he was worried by deflation or believed that monetary policy was insufficiently accommodating of the needs of the economy.

Glass-Steagall Doctrine. The Glass-Steagall Act of 1932 relaxed collateral requirements on Federal Reserve notes. In doing so it was a move away from gold standard doctrine. By expanding the range of securities against which the central bank could lend, it also constituted a rejection of the real bills doctrine (something of which the bill's reluctant cosponsor, Carter Glass, was painfully aware). It was an acknowledgment that the central bank should have the flexibility required to pursue other goals such as price stability, economic stability and financial stability. As such it was a transition in thinking from earlier conceptual frameworks to the monetary views of Franklin Delano Roosevelt and his Brains Trust.

But the Glass-Steagall Act was initially conceived as a temporary measure set to expire after one year. Thus, to characterize it as a new monetary doctrine is a stretch. The act was drafted by Treasury and Federal Reserve Board staff and sponsored by Glass and Henry Steagall, chairmen of the Senate and House Banking Committees. It reflected concerns on the part of Harrison and Eugene Meyer, chairman of the Federal Reserve Board, that eligible securities were growing increasingly scarce as the Depression deepened. As securities on the Reserve Banks' balance sheets matured but more were not offered for discount (regardless of the rate), Reserve Banks were forced to substitute gold, where they had it, for other backing for their note issue and to take steps to actively contract the note issue (through open market sales of government securities), where they lacked additional, or “free," gold. ${ }^{25}$

In principle, there was a third alternative, namely abandoning the gold standard. Treasury Secretary Ogden Mills warned President Hoover in early 1932 that the Federal Reserve, short of free gold but reluctant to further restrict the money supply, might be forced to contemplate this step. ${ }^{26}$ Reflecting the continuing influence of gold standard doctrine, all

\footnotetext{
${ }^{25}$ Those sales of securities would have forced member banks to borrow at the discount window, furnishing the Fed with additional eligible paper to count as collateral, as noted by Board of Governors (1933).

${ }^{26}$ Hoover (1952), pp.115-6.
} 
involved quickly concluded that it was better to modify the provisions making for gold backing of Federal Reserve notes rather than abandoning them entirely.

Under the Glass-Steagall Act passed on February $27^{\text {th }}, 1932$, government securities were made eligible as collateral for the note issue. Reserve Banks were authorized in addition to lend on previously ineligible commercial paper, broadening the range of assets against which member banks could borrow. ${ }^{27}$ This initiative reflected a shift in prevailing monetary-policy thinking away from the rules of the gold standard and the real bills doctrine toward the more discretionary approach favored by, inter alia, Benjamin Strong. What was initially seen as a temporary expedient then became permanent policy, partly because the circumstances of February 1933, when the act was set to expire, were so extreme, but also because the explosion of inflation and financial speculation feared by critics of the act failed to materialize. That experience in turn informed the belief, developed by FDR and his advisors in the course of 1933, that monetary policy should be enlisted in the pursuit of price stability and economic recovery.

Roosevelt Doctrine. If characterizing Glass-Steagall as monetary doctrine is a stretch, then describing FDR's monetary policies as being informed by an explicit monetary doctrine would be an absurdity. Roosevelt was an experimentalist; he was more inclined to try out a policy on an ad hoc basis and see whether it worked than to allow his actions to be dictated by a particular doctrinal framework.

Reflecting this, the president was counseled by several different groups of advisors with different views of policy, and he was inclined, as in other contexts, to adopt elements of the advice given by each group even when contradictory. In one camp was William Woodin, FDR's first treasury secretary and staunch believer in the gold standard. Several members of the delegation that Roosevelt sent to the World Economic Conference in mid-1933 were similarly predisposed toward maintenance of that system. ${ }^{28}$

At the other end of the doctrinal spectrum were George Warren and his fellow inflationists. An agricultural economist at Cornell University, Warren had served on the Agricultural Advisory Commission set up by then New York Governor Roosevelt to investigate farm problems, and he continued to advise FDR during the transition and after. Warren detected in the data a correlation between the dollar price of gold and the dollar price of agricultural commodities, leading him to advocate higher gold prices as a solution to farm problems and then to the problems of the economy as a whole. His arguments were lent a veneer of academic respectability by Yale University economists James Harvey Rogers, an expert on the gold standard but also a believer that the system could be managed, and Irving Fisher, by this time something of a celebrity owing to his theory of the compensated dollar. ${ }^{29}$

\footnotetext{
${ }^{27}$ Initially, eligibility had been limited to notes bearing on their face evidence that they grew out of specific commercial transactions or carrying a stamp certifying that the borrower had filed with the rediscounting bank a sworn financial statement indicating that the discounted paper was self-liquidating. The sworn-statement provision was eliminated subsequently, but other restrictions remained.

${ }^{28}$ Delegates so inclined included James Cox, former governor of Ohio, and arguably Cordell Hull.

${ }^{29}$ Fisher was precluded from serving as a formal advisor to the president by his advocacy of eugenics, status as a prohibitionist, and notorious "high plateau" argument made of the stock market in 1929, but he still had extensive contacts with FDR and his circle (as described by Barber 1996). On the compensated dollar plan see de Boyer des Roches and Betancourt (2012).
} 
How these contradictory positions might be reconciled was never clear; Roosevelt's response was to embrace them all and ignore the conflict. He allowed his treasury secretary to assert that the suspension of the gold standard in March was temporary. When the Thomas Amendment to the Agricultural Adjustment Act in April then authorized the president to raise the dollar price of gold by as much as 50 per cent, he took no action. He allowed his delegates to the World Economic Conference to negotiate an agreement implying an eventual return to the gold standard but then blew it and them out of the water with his bombshell message in July. His gold buying program starting in October pushed up the dollar price of gold, consistent with the views of the inflationists of the importance of restoring commodity prices to pre-Depression levels, but he then rejected their counsel, and that of John Maynard Keynes, by pegging the price of gold at \$35 an ounce in January 1934, thereby restoring select elements of the earlier gold standard. This may have been the reflationary monetary policy the economy needed, but it was not a policy informed by a consistent doctrine.

If there was a Roosevelt Doctrine, it was that monetary policy was best made by an entity other than the central bank until the latter was reorganized, with guidance from Roosevelt's hand-picked reformers, and got its act together, as it were.

\section{Episodes}

In this section I describe a number of key episodes in Federal Reserve policy in the 1920s and 1930s, focusing on cases where international considerations played a role, and analyze how the doctrines described above interacted to shape policy.

The Downturn of 1920-1. The 1920-1 recession was the first major downturn on the new central bank's watch. As is the case of most recessions, a combination of factors contributed to the cyclical swing; the task is to prioritize them. And among those priorities, modern scholars argue, were monetary policies dictated by gold standard doctrine.

U.S. prices had risen sharply during World War I. ${ }^{30}$ Gold standard doctrine now pointed to the desirability, and indeed the necessity if the statutory gold price of $\$ 20.66$ was to be maintained, of pushing them back toward prewar levels. Internal devaluation, in the form of the requisite wage and price adjustments, was seen as the appropriate adjustment mechanism by adherents to this doctrine.

Once-high U.S. gold ratios began falling following the armistice, from 48.3 per cent of the note issue at the end of the war to just 43.5 per cent in December 1919, alarmingly close to the statutory minimum. The New York Fed, particularly exposed to international financial pressures, saw its reserves fall to an even lower 40.2 per cent. System-wide, the reserve ratio then fell further, to an alarmingly low 40.9 per cent, in May 1920.

How had a once impregnable reserve position fallen to such worrisome levels? First, the U.S. removed its wartime embargo on gold exports in June 1919, making it an obvious source of gold for other countries seeking to replenish their reserves. Second, the Reserve Banks and the Board were precluded from more aggressively raising discount rates in 1919, so as to halt inflation and stem gold exports, by their role in supporting placement of the Victory Loan (the successor to wartime Liberty Loans), as needed to fund the Treasury's ongoing deficits (which

\footnotetext{
${ }^{30}$ Inflation as measured by the GDP deflator ran at 17 per cent in 1917, 19 per cent in 1918 and 14 per cent in 1919.
} 
were not easily eliminated, given constraints on the pace of postwar demobilization) and then in aiding Treasury efforts to roll over its short-term debt. The situation was not unlike that following World War II, when efforts by the Federal Reserve to peg the interest rates on U.S. Treasury obligations led to several sharp bursts of inflation.

This combination of low discount rates, inflation and the end of the export embargo made gold losses inevitable. Gold standard doctrine counseled increases in the rediscount rate to stem those losses and accelerate internal adjustment. ${ }^{31}$ Discussion of this option became increasingly urgent once the Victory Loan was successfully placed.

The objection to this explanation for the decision to raise discount rates in 1919-20 is the observation that the Federal Reserve, in principle, could have temporarily suspended reserve requirements. This alternative is emphasized by critics of the present interpretation such as Kuehn (2011). But the gold standard mentalité militated against such unconventional action. And had the Fed temporarily suspended its gold-backing requirements in order to avoid raising the discount rate, it is not clear what other mechanism would have prevented reserve ratios from falling further and gold reserves from being exhausted.

On November 3, 1919, the directors of the New York Fed, aware of the precarious position of their bank, voted to raise discount rates for various categories of paper by 0.25-0.75 per cent from prevailing levels of 4.0 per cent. Quickly four other Reserve Banks followed. With the gold reserve ratio continuing to fall, New York then raised the rate it charged for discounting government paper to 5 per cent in April and $51 / 2$ per cent in July. It raised its discount rate for commercial paper even more sharply, to 7 per cent by mid-1920. Again, other Reserve Banks followed. These increases in policy rates now succeeded in inducing the sharp fall in prices prescribed by gold standard doctrine. That in turn led to a reversal in the direction of gold flows and an increase in reserve ratios system-wide and at the New York Fed in particular.

Along with gold standard doctrine, the real bills and Strong doctrines played a role in these decisions. The Annual Report of the Board of Governors' for 1920 pointed to the tendency for banks to extend credit to finance "speculation in corporate stocks and securities [and]...”unsold goods in storage” (commodity speculation of a non-self-liquidating sort) as opposed to the legitimate business transactions privileged by the real bills doctrine, and invoked this as an argument for raising rates. ${ }^{32}$ Strong's correspondence documents the importance he attached in this period, in addition, to restoring the international gold standard, starting in the United States but extending to Europe, as the basis for domestic and international prosperity. ${ }^{33}$ Interest rate increases might be painful in the short run, but they were necessary for achieving the longer-run goals to which Strong, and others who shared his view, attached priority.

Moreover, not everyone subscribed to the view that there would be pain in the short run. The Annual Report of the Board of Governors for 1920 rejected the notion that Federal Reserve policy precipitated the recession. The most policy did, the Board argued, was to "slow down the immediate tendency toward expansion." 34 Indeed, the short time span between the first interest

\footnotetext{
${ }^{31}$ So argue Friedman and Schwartz (1963), p.234.

32 Board of Governors (1921), p.12.

${ }^{33}$ See for example Chandler (1958), pp.122-4, 173-4.

${ }^{34}$ Board of Governors (1921), p.14.
} 
rate increases at the end of 1919 and the onset of recession in January 1920 (according to the NBER business cycle date) suggests that this objection was not baseless; the early date of the onset of recession suggests that other factors were also at work. Those other factors plausibly included postwar reductions in government contracting and spending (federal spending fell by nearly two-thirds between fiscal years 1919 and 1920) and increased union militancy and strike activity, leading to increases in labor costs.

But if Federal Reserve policy, and the gold standard, real bills and Strong doctrines informing it, did not bring on the recession, they at least played a role by amplifying and extending it. In addition, the fact that the economy bounced back sharply from the 1920-1 recession rendered Federal Reserve officials, and New York Fed officials in particular, favorably disposed toward increases in rates in the late stage of a financial boom on the next occasion one next developed, at the end of the 1920s.

Policy in 1924 and 1927. The Fed's expansionary policy actions in 1924 and 1927 are widely seen as two further instances when international considerations played a consequential role in decision making. These episodes are controversial. They are portrayed as having been shaped by Benjamin Strong and as disproportionately informed by the Strong doctrine. They are criticized for subordinating domestic conditions to international factors and therefore as feeding domestic instabilities. Out of consensus, there are also those who challenge the notion that the 1924 and 1927 policy actions were in fact motivated by international considerations.

As of 1924, reconstruction of the international gold standard was still far from complete. The pound sterling, the second linchpin of the international system, was still trading at a discount relative to 1914 levels, and the Bank of England lacked gold reserves sufficient to restore convertibility at the prewar parity. For Strong, who saw reconstruction of the international gold standard as a U.S. priority, this was a problem for the Federal Reserve Bank of New York and the System to address. With leadership from New York, the Reserve Banks reduced their discount rates from the $4 \frac{1}{1} 2$ per cent levels prevailing since early 1923 to 3-4 per cent between May and October of 1924. In addition, the Open Market Investment Committee authorized the New York Fed to purchase \$300 million of Treasury bonds, pushing down yields and encouraging capital and gold to flow across the Atlantic to Britain, in order to help the Bank of England replenish its reserves. Finally, the Federal Reserve Bank of New York provided a \$200 line of credit to the Bank of England in exchange for an equivalent amount of sterling deposit credit. $^{35}$

None of this was secret. In a 1924 statement prepared for the House of Representatives Committee on Banking and Currency, Strong cited international considerations as a rationale for lower discount rates and expansionary open market operations. These initiatives were designed "to render what assistance was possible by our market policy toward the recovery of sterling and resumption of gold payment by Great Britain.”36

The question is whether international considerations were the main explanation for the central bank’s accommodating stance. Commercial and industrial activity was relatively weak.

\footnotetext{
${ }^{35}$ With J.P. Morgan \& Co. providing a supplementary $\$ 100$ million credit.

${ }^{36} 69^{\text {th }}$ Congress, $1^{\text {st }}$ session, Stabilization, Hearings on H.R. 7895 before Cmomittee on Banking and Currency, part 1, p.336.
} 
The Board, in its Annual Report for 1924, noted that the industrial sector was in mild recession from mid-1923 to mid-1924, although trade volumes and farm incomes were both rising strongly. ${ }^{37}$ It could be that Fed officials were influenced by this industrial weakness, although none of the doctrines informing policy necessarily privileged the industrial sector or saw it as the Fed's responsibility to stabilize industrial production.

Since 1924 saw gold inflows, gold standard doctrine also counseled ease, special concerns with the Bank of England notwithstanding. The 1924 Annual Report cites gold inflows as "the most important single influence affecting the volume of Federal Reserve bank credit in use" during the year. ${ }^{38}$ There is also a clear statement of the Riefler-Burgess doctrine, pointing to the need to look to the level of short-term market rates as a measure of monetary conditions, given the tendency for open market operations and member bank rediscounts to move in offsetting directions. And commercial paper rates stayed stubbornly high (rising further in the third quarter of 1923), despite the weakness of industrial conditions. Finally, the Annual Report justified open market purchases in terms of the real bills doctrine, noting that "there was no evidence of the growth of speculation."39

My reading is that the impetus for discount rate reductions in May-October 1924 came mainly from the international side, since domestic weakness that might have motivated action was limited to industry and was largely over by the time policy makers moved. It helped that their decisions did not egregiously violate other prevailing policy doctrines.

The 1927 episode is even more controversial. Having returned to gold in April 1925, the Bank of England was struggling to stay there. A high exchange rate made for problems of trade competitiveness. Industrial unrest culminating in a coalminers' strike disrupted exports. Revenues from service exports continued to disappoint. And starting in 1926, the Reichsbank and Bank of France, having accumulated sterling claims, sought to convert them into gold.

Strong, in continuous contact with his friend and pen pal Montagu Norman, was aware of the latter's problems. In July 1927, at Norman's instigation, he convened a meeting with Hjalmar Schacht of the Reichsbank, and Charles Rist of the Bank of France, along of course with Norman himself, at the Long Island estate of Treasury Undersecretary Ogden Mills. Strong came away convinced of the need to cut rates in order to induce gold to flow toward London and relieve the pressure on the Bank of England. He saw to it that Norman, Schacht and Rist continued on to New York and Washington to meet with Daniel Crissinger, chairman of the New York Fed, and with the Board of Governors. Their meetings had the desired effect. Eight Reserve Banks, starting with Kansas City, voted to cut rates. The decision was then imposed on the dissenting Reserve Banks by the Board for the first time in the history of the System. In addition, the System undertook some $\$ 80$ million of open market purchases over the course of the summer.

With benefit of 20/20 hindsight, Strong's critics dismissed the policy as counterproductive. The reduction in policy rates gave an additional fillip to speculation in a period when financial markets were already frothy. It subsidized the provision of brokers' loans.

\footnotetext{
${ }^{37}$ Board of Governors (1925), p.1.

${ }^{38}$ Board of Governors (1925), p.8.

${ }^{39}$ Board of Governors (1925), p.12.
} 
In the words of Adolph Miller, Strong's leading critic on the Board, the decision gave "a further great and dangerous impetus to an already overexpanded credit situation, notably to the volume of credit used on the stock exchanges..."40 The Board's Annual Report for 1927 noted the disquieting growth of security loans by commercial banks, a phenomenon not obviously compatible with the real bills doctrine, but did not comment further on the conflict. ${ }^{41}$

Once more, however, there were other factors pointing in the direction of a more expansionary policy, again raising the question of whether it was really the Strong doctrine that carried the day. The U.S. was on the receiving end of gold inflows in the first part of the year, which dictated some relaxation of policy according to conventional gold standard logic regardless of the situation of the Bank of England. However, those gold inflows had clearly ended by June - that is, in advance of the reduction in policy rates. The U.S. experienced a coal strike starting in April and then weakness in manufacturing production as Henry Ford closed down his assembly lines to retool from the Model $\mathrm{T}$ to the Model A. As a result, industrial production was weak in the second half of the year. In justifying its discount rate reductions, the Board of Governors pointed to the "recession in business in the United States" that became evident around the middle of the year. It pointed to "the tendency toward firmer conditions in the money market," consistent with the focus of the Riefler-Burgess doctrine on short-term market rates. But it wrote most extensively about the international situation. ${ }^{42}$ Clarke concludes on this basis and from the minutes of the Open Market Investment Committee that "external considerations probably weighed more heavily than domestic ones."43

The Crash and its Aftermath. Its response to the Great Crash is widely cited as demonstrating that the Fed was capable of committing egregious policy errors without any role for international considerations. This statement is half right. It is right in that international factors played little role in the policy decisions of late 1929 and 1930. The Board in its Annual Report for 1929 did seek to deflect attention from its policy of direct pressure and from increases in the discount rate of the Federal Reserve Bank of New York as factors in the stock market crash by citing the role of an "important failure of a finance company in England [the Hatry Scandal]," which resulted in a loss of confidence by British investors and some withdrawals of foreign funds from the New York market. It pointed to the 100 basis point discount rate increase by the Bank of England on September $26^{\text {th }}$ as creating stringency in New York. ${ }^{44}$ It noted also that gold inflows reversed direction starting in October. After rising by some $\$ 250$ million in the previous 10 months, the monetary gold stock fell by \$100 million in November and December, as foreigners previously attracted by high interest rates and a soaring stock market repatriated their funds.

\footnotetext{
${ }^{40}$ Miller (1935), p.449.

${ }^{41}$ Board of Governors (1928), pp.5-6.

42 "During this period it also became evident that there was a serious credit stringency in European countries generally, and it was felt that easy money in this country would help foreign countries to meet their autumn demand for credit and exchange without unduly depressing their exchanges or increasing the cost of credit to trade and industry. Easier credit conditions abroad would also facilitate the financing of our exports and would thus be of benefit to American producers. By purchasing securities at that time the Federal reserve banks wer ein fact successful in easing the condition of the money market and in exerting a favorable influence on the international financial situation.” Board of Governors (1928), p.10.

${ }^{43}$ Clarke (1967), p.125.

44 “This series of events," it went on, “culminated in the last week in October in a break of unprecedented severity in stock prices...” Board of Governors (1930), p.9.
} 
Conventional gold standard doctrine dictated tightening. In fact, this is contrary to how the Fed responded. Informed by the Strong and Harrison doctrines, it instead neutralized the impact of gold outflows with expansionary open market operations. In the last week of October, Reserve Banks purchased \$150 million of government securities, purchases that continued into November and December. The Federal Reserve Bank of New York took the lead, purchasing securities for its own account; after a short dispute over with whom the authority to authorize purchases ultimately rested, the Board endorsed the policy. ${ }^{45}$ Cumulative open market purchases in the eight months ending in June 1930 were \$400 million. Charles Hardy, a contemporary observer of the central bank, characterized these purchases as "enormous," not our retrospective evaluation perhaps but an indication of how they looked at the time. ${ }^{46}$

These actions were intended to prevent distress among member banks "taking over in large volume loans previously carried by nonbanking lenders..."47 This quick action by a central bank that understood how to respond to financial stringency caused by stock-market problems, like those of 1907 and 1914, averted a wave of bank failures in New York. It prevented stringency in money markets and a spike in money-market rates. In other words, the commonplace characterization that the Fed stood by while the financial system was crashing down is not an accurate portrayal of its actions in 1929.

But having provided emergency liquidity sufficient to prevent a wave of bank failures, Federal Reserve officials concluded that their work was done. The real bills doctrine pointed to the discount rate and level of discounts as indicating whether further loosening of policy was warranted. The Federal Reserve Bank of New York was able to reduce its discount rate from 6 to 5 per cent on November $1^{\text {st }}$ and $4 \frac{1}{2} 2$ per cent on November $15^{\text {th }}$. Six more Reserve Banks followed suit by January 1930. Rates were then reduced further, to 2 per cent in New York, 2 1/2 per cent in Boston and 3 per cent in Cleveland, Atlanta, Chicago, St. Louis and San Francisco, and 3 1/2 per cent in Philadelphia, Richmond, Minneapolis, Kansas City and Dallas over the course of $1930 .^{48}$ None of this resulted in the Reserve Banks being flooded with speculative discounts, reassuring adherents to the real bills doctrine. The Riefler-Burgess doctrine pointed to the level of short-term market interest rates as a measure of the stance of policy, and these too declined in the wake of the crash.

But in this, a period when the price level was falling (wholesale prices declined by more than 10 per cent in the course of 1930), it became apparent that Federal Reserve doctrine drew no distinction between real and nominal interest rates. Insofar as officials were aware that the price level was falling, they rejected the claim that price-level stabilization was a legitimate goal of policy. They warned that efforts to stabilize prices might be interpreted as a mandate to fix the prices of specific commodities, farm products for example. They objected that pursuing stable prices could conflict with other legitimate goals of policy, such as preventing the excessive use of central bank credit for speculative purposes. They asserted that the central bank lacked the

\footnotetext{
${ }^{45}$ Meltzer (2003), p.236.

${ }^{46}$ Hardy (1932), p.56.

${ }^{47}$ Board of Governors (1930), p.10.

${ }^{48}$ Including the first days of 1931.
} 
capacity to stabilize prices, anticipating arguments about pushing on a string in liquidity-trap-like conditions. $^{49}$

Modern scholarship has answers to all these objections. Making the central bank strongly independent and giving it an explicit price level mandate can allow it to pursue a price-stability goal without succumbing to lobbying by specific commodity producers. If pursuit of price stability threatens financial stability, then the central bank should develop other instruments what we would call "macroprudential" tools - to contain those risks. ${ }^{50}$ Even if there was no demand for Federal Reserve credit at prevailing low interest rates, then the Fed still could have influenced price-level developments through additional open market or gold market purchases (quantitative easing) and statements of intent designed to shape expectations (forward guidance), as was done in 1933, although these steps were not obviously compatible with gold standard doctrine (just as their implementation in 1933 required first suspending the gold standard). ${ }^{51}$

Be this as it may, Federal Reserve policy in 1930 was informed not by modern scholarship but by the real bills, Riefler-Burgess and gold standard doctrines.

1931. The period from May through December 1931 was a clear instance where international considerations dominated decision making. As the Board of Governors put it, "Throughout the year unfavorable developments abroad were an important factor in business and credit conditions in the United States." 52 The Strong doctrine attached great importance to a stable international monetary system, which now began to unravel with the crises in Austria and Germany.

Much like Strong in 1924, Harrison took the lead in mobilizing the resources of the Federal Reserve System to support other embattled countries. In mid-May, he requested approval from the Board to contribute up to \$3 million to an emergency loan to Austria, which the Board quickly approved. ${ }^{53}$ In late June, the crisis having spread to Germany, Harrison obtained the approval of the Board to extend a much larger credit, up to \$50 million, to the Reichsbank. In the end, with the Bank for International Settlements, the Bank of England and the Bank of France participating, the U.S. share of the $\$ 100$ million requested by German officials was limited to $\$ 25$ million. But even the full \$100 million was small relative to the liabilities of the German banking system, liabilities that now continued to hemorrhage out of the country. There is an obvious analogy with the dollar swap lines extended by the Federal Reserve to the ECB, the Swiss National Bank, and the central banks of four emerging markets in the 2008-9 crisis.

\footnotetext{
${ }^{49}$ The list of objections goes on; the complete set is enumerated in Hardy (1932), Chapter 10.

${ }^{50}$ Naturally, the Fed's recent failed experiment with such a policy, “direct pressure” in 1929, did not incline it toward this view.

51 The Fed had been able to ignore its $\$ 100$ million of gold losses when purchasing \$150 million of government securities in the final months of 1929 because those losses were small and it had excess reserves given the large gold inflows earlier in the year. Whether it would have been able to maintain the statutory cover ratio in the face of the much larger counterfactual open market purchases needed to stabilize prices in 1930 is an entirely different question.

${ }^{52}$ Board of Governors (1932), p.2.

${ }^{53}$ With the Austrian crisis quick to spill over to Hungary, a similar loan was arranged for the National Bank of Hungary,again with Fed participation.
} 
The next stage developed less positively. To stay on the gold standard, the Reichsbank needed a second credit. Efforts to organize this foundered over French unhappiness with the German government's failure to comply with the terms of the Versailles Treaty. Paris saw the currency crisis as an opportunity to force Berlin into line and made impossible demands on the German government. ${ }^{54}$ In addition, Harrison and others feared that their loans were simply financing capital flight. Flight by foreign banks could be halted or at least slowed by a standstill agreement like that negotiated by Austria with its foreign creditors. But Harrison worried that much of the capital flight in question was in fact the transfer abroad of funds by Germans unsettled by the country's tumultuous politics. This could only be halted by shutting down the German banking system, something that was inconsistent with the Strong doctrine of supporting international transactions.

In the end, efforts to organize a second German loan were unsuccessful; Germany was forced to impose controls, and the crisis leapfrogged to London. Harrison understood that sterling was a key international currency, and that the survival of the gold standard system turned on its fate. He hoped that the Fed could work with other central banks and the private banking community to assemble an overwhelming show of force. The central banks would provide credits to the Bank of England, while other banks would extend a loan to the British government. In the event, shock and awe proved infeasible. The central bankers wanted the British government (governments, actually, since one replaced another in August) to implement a domestic policy package, budgetary economies mainly, to support the currency, which was easier said than done. The private bankers were reluctant to participate on any terms.

As a result, the emergency aid dribbled out. In July, with laborious negotiations underway, the New York Fed purchased some \$10 million of sterling on the foreign exchange market. On July $30^{\text {th }}$ the directors of the New York Fed and the Board of Governors finally approved a \$125 million credit to the Bank of England - a much smaller amount than requested and less than Britain ultimately required. ${ }^{55}$ It then took another month for Harrison to arrange a \$200 million loan to the British government by a consortium of U.S. banks headed by J.P. Morgan. Although these resources were an order of magnitude larger than those previously provided to Austria, they were again too little, too late.

The story of Britain's suspension of gold convertibility has been told elsewhere. What matters for present purposes is the Fed's response. Sterling's depreciation created a demand for liquidity which foreigners obtained by repatriating funds from New York. It excited fears that the dollar might be devalued, making for gold losses for the New York Fed in particular. Although the gold reserves of the System still substantially exceeded the 40 per cent minimum, the argument that the central bank needed to signal its commitment to maintenance of the gold standard was compelling against this unsettled backdrop. ${ }^{56}$

\footnotetext{
${ }^{54}$ The French government demanded that Germany drop its customs union proposal, commit to full resumption of reparations payments, and renounce rearmament spending as a precondition for further assistance. This was impossible for Chancellor Brüning, who had staked himself politically to an aggressive foreign policy.

${ }^{55}$ The Bank of France provided a matching \$125 million credit and similarly intervened to support sterling on the foreign exchange market.

${ }^{56}$ Friedman and Schwartz (1963) agree. As they write (p.382) of this episode, "The sharp rises in discount rates were widely supported not only within the System but also outside. The maintenance of the gold standard was accepted as an objective in support of which men of a broad range of view were ready to rally. The drain of gold
} 
Consistent with gold standard doctrine, the New York Fed raised its rate from $1 \frac{1 / 2}{2}$ to $2 \frac{1}{2}$ per cent on October $8^{\text {th }}$ and then to $3 \frac{1 / 2}{2}$ per cent on October $16^{\text {th }}$. This was the largest increase in a Reserve Bank discount rate in a two-week period in the history of the System. By midNovember that 3 1/2 per cent level had been matched by the other Reserve Banks. ${ }^{57}$ Rather than sterilizing gold outflows to prevent the money supply and prices from falling further, the Federal Reserve allowed its holdings of government securities to fall by $\$ 15$ million between midSeptember and the end of the year. All this was done, recall, in the depths of the Depression, when prices and output were collapsing. There is no question about which doctrine carried the day. Even those like George Harrison with other concerns now subordinated them to defense of the gold standard, an objective that had similarly been prioritized by his mentor Benjamin Strong.

After Glass-Steagall. As gold continued flowing out of the country in the final months of 1931, the free gold constraint increasingly looked ready to bind. This led to passage in February 1932 of the Glass-Steagall Act loosening collateral requirements for Federal Reserve notes, as described above. By allowing the Federal Reserve Banks to back their liabilities with government bonds above the 40 per cent gold minimum, it gave the System, with gold reserves of 70 per cent of liabilities, room to engage in expansionary open market operations.

It also represented a doctrinal shift, among the Fed's critics if not necessarily also officials of the Federal Reserve itself. Pre-Glass-Steagall restrictions on what assets were eligible as backing for Federal Reserve notes reflected the sway of the real bills doctrine. The Fed, those restrictions indicated, should discount and purchase only high quality commercial paper generated in the course of normal business transactions. By removing this restriction and adding government bonds to the list of eligible assets, this new legislation generated in the Treasury and the White House and passed overwhelmingly by the Congress sent the Fed a clear signal that the central bank should contemplate broader objectives. As Meltzer puts it, "The System could not ignore the message in this action." 58

Nor was the message limited to Glass-Steagall. Representative Thomas Goldsborough, Democrat from Maryland, was campaigning for a bill that would have required the Federal Reserve to take steps to raise prices to 1926 levels. Senator Elmer Thomas, Democrat of Oklahoma, had begun lobbying for a bill that would have required the Federal Reserve to print an additional $\$ 2.4$ billion of essentially uncollateralized notes. ${ }^{59}$ Other prospective legislation foresaw early payment of the World War I Veterans Bonus to be financed by issuance of Federal Reserve notes.

Federal Reserve officials saw these initiatives as unsound. They were inflationary. They were a threat to the gold standard. They endangered financial stability. They were at odds, in other words, with the doctrinal foundations of Federal Reserve policy, regardless of where that doctrinal basis was found. They also represented a threat to the independent conduct of monetary policy, such as it was. If there was going to be unsound monetary policy, better there

was a dramatic event for which there were many precedents. Thus both the problem and its solution seemed clear and straightforward.”

${ }^{57}$ Richmond and Dallas went up to 4 per cent.

${ }^{58}$ Meltzer (2003), p.357.

${ }^{59}$ A campaign that, in a sense, came to fruition with the Thomas Amendment to the Agricultural Adjustment Act in 1933. 
should be a little than a lot, Federal Reserve officials were led to conclude. Better it should be implemented by the central bank's in-house experts rather than populist politicians.

Between March and May, the Fed thus engaged in a sustained program of expansionary open market operations, purchasing \$1 billion of government debt, sufficient to offset roughly 20 per cent of the cumulative decline in M1 from its peak in 1929 to its winter of 1932 trough.

In July the central bank then halted its open market operations. Why the Fed halted them is easier to explain on doctrinal grounds than why it initiated them in March. ${ }^{60}$ Interest rates, having spiked in late 1931 and early 1932, had now begun falling again and were below the levels reached prior to Britain's devaluation. ${ }^{61}$ Member bank borrowing from the System had declined; any Riefler-Burgess-based arguments for easing that might have prevailed at the beginning of 1932 no longer held. Bank liquidity had continued to rise, further agitating real bills advocates who worried about a burst of speculative lending. The Federal Reserve System had experienced steady gold losses in the spring and early summer. ${ }^{62}$ Those gold losses were particularly heavy in May and June. Conventional gold standard doctrine dictated monetary tightening in response.

By the end of June the gold reserve ratio of the Federal Reserve Bank of New York, in particular, had fallen to barely 50 per cent and was headed lower, creating concerns for Harrison and his Board. ${ }^{63}$ Other Reserve Banks with bigger fish to fry (the Chicago Fed was faced with the possible failure of the Dawes Bank and other metropolitan banks to which it was linked and was therefore anxious to husband its reserves) were reluctant to continue participating in the open market program, suggesting that were it to continue a disproportionate share of purchases would have to be undertaken by New York. ${ }^{64}$ Bordo, Choudhri an Schwartz (2002) and Hsieh and Romer (2006) reject the argument that those gold losses raised the specter of an imminent gold-standard crisis and that it was in response to such a crisis that the Fed drew back in July. This, in my view, is not the point. What mattered was not the specter of an imminent crisis but gold-standard doctrine broadly defined - the gold-standard mentalite that suggested tightening when gold flowed out and loosening when it flowed in. That plus the fact that the Congress adjourned for the summer on July $16^{\text {th }}$, removing the pressure for reflation and allowing other doctrinal imperatives to carry the day.

\section{Conclusion}

The era from 1914 to 1933 was one in which the fledgling Federal Reserve System, like a child learning to walk, struggled to find its policy making feet. There were also notable lapses in this period, mainly after 1929, when the Fed, like an infant taking its first tentative steps, failed to maintain its footing.

\footnotetext{
${ }^{60}$ The decision to initiate them in March, I have argued, is easier to explain on political than doctrinal grounds.

${ }^{61}$ Friedman and Schwartz (1963), p.323 provide additional detail.

62 Those gold losses of more than $\$ 400$ million offset nearly half of the open market expansion.

63 The reserve ratio of the System as a whole was still 56 per cent. On the concerns of Harrison and the directors of the New York Fed, see Meltzer (2003), p.369.

${ }^{64}$ Epstein and Ferguson (1984) explain the conflict between Chicago and New York differently, arguing that banks in the Chicago district were heavily invested in short-term government bonds, while banks in New York had portfolios heavy on long-term bonds. Coelho and Santoni (1991) question their interpretation.
} 
Policy in this period was guided by different monetary policy frameworks, some of which, like the real bills doctrine, placed little weight on international considerations, but others of which, like gold standard doctrine, attached to them the highest priority. The Warburg doctrine emphasizing the desirability of internationalizing the dollar and the Strong doctrine prioritizing reconstruction of the international gold standard similarly directed officials to external and international dimensions of the new central bank's policies. In contrast, the RieflerBurgess and Glass-Steagall doctrines, while otherwise having little in common, downplayed international factors in favor of domestic market conditions.

In the same way a young child just beginning to walk has not yet learned how to put one foot in front of the other, officials within the Federal Reserve System had not yet figured out on which of these doctrines to lean when formulating policy. The influence of different doctrinal foundations waxed and waned as a function of personnel and personality. Their influence varied with circumstance: gold standard doctrine was more likely to be influential when the Fed's gold cover ratio was low relative to statutory requirements than when it was high; and the Strong doctrine emphasizing the importance of a stable international monetary system was more likely to influence central bank policy when that system was perceived to be at risk. On other occasions, international considerations faded into the background. There were also clear differences of opinion about the importance of international considerations in different parts of the Federal Reserve System - differences that manifested themselves in conflicts between New York and other Reserve Banks.

Finally, what does modern central banking doctrine say about the role of international considerations in the conduct of policy in this period? It suggests that the Fed was right not to ignore conditions in the rest of the world. U.S. policy could and did have a first-order impact on other countries, such as the UK and Germany. And what happened in the UK and Germany didn't stay in the UK and Germany; rather, the spillback effects of developments there could be considerable. The same is true of threats to the stability of the international monetary and financial system as distinct from individual countries. When the stability of the system was threatened in 1931, the impact on the U.S. economy was considerable; these were not developments that a prudent central bank could neglect.

That said, Federal Reserve officials could have dealt more wisely with the international aspects of policy. Attempting to reconstruct an international gold standard along prewar lines in social, political and economic circumstances that were now radically changed was not the wisest decision. But once that decision was taken, the Fed either should have either supported the resulting system wholeheartedly or else acknowledged that the experiment was a failure and abandoned it. The half-measures taken in 1931 to support Austria, Germany and the United Kingdom solved nothing. The sharp increases in Federal Reserve discount rates taken in the wake of these European crises, with the goal of defending what remained of the gold standard, only further weakened the U.S. economy and the banks while again solving nothing. At this late date the Fed's response only delayed the inevitable, namely the suspension of dollar convertibility.

The other lesson of this period is that even a central bank with good reason to worry about economic and financial conditions in the rest of the world will achieve nothing if it fails to attend to the health and stability of its own economy. This was true of the Fed in the 1920s and 1930s. The same is true today when we hear calls for the Federal Reserve to abandon policies tailored to 
the needs of domestic stability in order to address problems in the rest of the world. 


\section{References}

Andrew, Piatt (1905), “Credit and the Value of Money,” Publications of the American Economic Association 6, pp.95-115.

Barber, William (1996), Designs within Disorder: Franklin D. Roosevelt, the Economists, and the Shaping of American Economic Policy, 1933-1945, New York: Cambridge University Press.

Board of Governors of the Federal Reserve System (1921), Seventh Annual Report of the Federal Reserve Board, Washington, D.C.: Government Printing Office.

Board of Governors of the Federal Reserve System (1925), Eleventh Annual Report of the Federal Reserve Board, Washington, D.C.: Government Printing Office.

Board of Governors of the Federal Reserve System (1928), Thirteenth Annual Report of the Federal Reserve Board, Washington, D.C.: Government Printing Office.

Board of Governors of the Federal Reserve System (1930), Fifteenth Annual Report of the Federal Reserve Board, Washington, D.C.: Government Printing Office.

Board of Governors of the Federal Reserve System (1932), Seventeenth Annual Report of the Federal Reserve Board, Washington, D.C.: Government Printing Office.

Board of Governors of the Federal Reserve System (1933), Eighteenth Annual Report of the Federal Reserve Board, Washington, D.C.: Government Printing Office.

Bordo, Michael, Ehsan Choudhri and Anna Schwartz (2002), "Was Expansionary Monetary Policy Possible During the Great Contraction? An Examination of the Gold Standard Constraint," Explorations in Economic History 39, pp.1-28,

Broz, Lawrence (1997), The International Origins of the Federal Reserve System, Ithaca, New York: Cornell University Press.

Brunner, Karl and Allan Meltzer (1968), "What Did We Learn from the Monetary Experience of the United States in the Great Depression?” Canadian Journal of Economics 2, pp.334-348.

Burgess, W. Randolph (1964), "Reflections on the Early Development of Open Market Policy," Federal Reserve Bank of New York Monthly Review 36, pp.219-226.

Chandler, Lester (1958), Benjamin Strong, Central Banker, Washington,,D.C: Brookings Institution Press.

Clarke, Stephen (1967), Central Bank Cooperation 1924-31, New York: Federal Reserve Bank of New York.

Coelho, Philip and Gary Santoni (1991), "Regulatory Capture and the Monetary Contraction of 1932: A Comment on Epstein and Ferguson,” Journal of Economic History 51, pp.182-189.

De Boyer des Roches, Jerome and Rebeca Gomez Betancourt (2012), “Origins and Development of Irving Fisher's Compensated Dollar Plan,” unpublished manuscript, Paris Dauphine and University of Lumiere Lyon (June). 
Eccles, Marriner and Sydney Hyman (1951), Beckoning Frontiers: Public and Personal Recollections, New York: Alfred A. Knopf.

Eggertsson, Gauti (2008), “Great Expectations and the End of the Depression,” American Economic Review 98, pp.1476-1516.

Eichengreen, Barry (1992), Golden Fetters: The Gold Standard and the Great Depression, 19191939, New York: Oxford University Press.

Eichengreen, Barry (2013), “Does the Federal Reserve Care About the Rest of the World?” Journal of Economic Perspectives 27, pp.87-104.

Eichengreen, Barry and Marc Flandreau (2012), “The Federal Reserve, the Bank of England, and the Rise of the Dollar as an International Currency, 1914-39,” Open Economies Review 23, pp.57-87.

Eichengreen, Barry, Livia Chitu, Arnaud Mehl and Gary Richardson (2014), "Mutual Assistance between Federal Reserve Banks 1913-1960 as Prolegomena to the TARGET2 Debate,” NBER Working Paper no. 20267 (June).

Eichengreen, Barry and Peter Temin (2000), “The Gold Standard and the Great Depression,” Contemporary European History 9, pp.183-207.

Epstein, Gerald and Thomas Ferguson (1984), "Monetary Policy, Loan Liquidation, and Industrial Conflict: The Federal Reserve and the Open Market Operations of 1932,” Journal of Economic History 44, pp.957-983.

Fishback, Price (2010), “U.S. Monetary and Fiscal Policy in the 1930s,” Oxford Review of Economic Policy 26, pp.385-413.

Friedman, Milton and Anna Schwartz (1963), A Monetary History of the United States 18671960, Princeton: Princeton University Press.

Goldstein, Judith (1994), Ideas, Interests and American Trade Policy, Ithaca: Cornell University Press.

Hardy, Charles (1932), Credit Policies of the Federal Reserve System, Washington, D.C.: Brookings Institution.

Hay, Colin (2004), "Ideas, Interests and Institutions in the Comparative Political Economy of Great Transformations,” Review of International Political Economy 11, pp.204-226.

Hetzel, Robert (1985), “The Rules versus Discretion Debate over Monetary Policy in the 1920s," Federal Reserve Bank of Richmond Economic Review 71, pp.3-14.

Hoover, Herbert (1952), Memoirs, Volume 3: The Great Depression, 1929-41, New York: Macmillan.

Hsieh, Chang-Tai and Christina Romer (2006), "Was the Federal Reserve Constrained by the Gold Standard During the Great Depression? Evidence from the 1932 Open Market Purchase Program,” Journal of Economic History 66, pp.140-176. 
Humphrey, Thomas (1982), “The Real Bills Doctrine,” Federal Reserve Bank of Richmond Economic Quarterly 68, pp.3-13.

Humphrey, Thomas (2001), "The Choice of a Monetary Policy Framework: Lessons from the 1920s,” Cato Journal 21, pp.285-313.

Hyman, Sidney and George Bach (1976), Marriner S. Eccles: Private Entrepreneur and Public Servant, Stanford, Calif.: Graduate School of Business Press.

Keynes, John Maynard (1925), The Economic Consequences of Mr. Churchill, London: Macmillan.

Kuehn, Daniel (2011), “A Critique of Powell, Murphy and Woods on the 1920-21 Depression,” Review of Austrian Economics 24, pp.273-291.

Laidler, David (1981), “Adam Smith as a Monetary Economist,” Canadian Journal of Economics 14, pp.185-200.

Law, John (1705), Money and Trade Considered, Edinburgh: Heirs and Successors of Andrew Anderson.

Meltzer, Allan (2003), A History of the Federal Reserve, Volume 1: 1913-1951, Chicago: University of Chicago Press.

Miller, Adolph (1935), “Responsibility for Federal Reserve Policies 1927-29,” American Economic Review 25, pp.442-457.

Patinkin, Don (1993), “Irving Fisher and His Compensated Dollar Plan,” Federal Reserve Bank of Richmond Economic Quarterly 79, pp.1-34.

Rothbard, Murray (2011), Economic Controversies, Auburn, Alabama: Ludwig von Mises Institute.

Steiner, William (1922), The Mechanism of Commercial Credit: Terms of Sale and Trade Acceptances, New York: Appleton \& Co.

Timberlake, Richard (2005), "Gold Standards and the Real Bills Doctrine in U.S. Monetary Policy,” Economic Journal Watch 2, pp.196-233.

Warburg, Paul (1914), Essays on Banking Reform in the United States, New York: Academy of Political Science.

Wheelock, David (1991), The Strategy and Consistency of Federal Reserve Monetary Policy 1924-1933, Cambridge: Cambridge University Press. 